\title{
KERAGAAN LIMA VARIETAS SORGUM PADA TANAH ULTISOL DI DESA PETUNANG KABUPATEN MUSI RAWAS
}

\author{
Samsul Bahri, Holidi, Reka Desantra \\ Fakultas Pertanian Universitas Musi Rawas \\ * Penulis korespondensi \\ Email: bahriunmura@gmail.com
}

\begin{abstract}
ABSTRAK
Penelitian ini untuk melihat keragaan dari beberapa varietas tanaman sorgum yang dibudidayakan pada tanah ultisol di Desa Petunag Kabupaten Musi Rawas. Penelitian ini disusun menggunakan metode rancangan acak lengkap (RAK) non faktorial dengan perlakuan lima vareitas tanaman sorgum diantaranya Varietas Pahat, Varietas Kawali, Varietas Numbuh, Varietas Suri 4 dan Varietas Super 1. Hasil penelitian menunjukan bahwa varietas numbu yang dibudidayakan pada tanah ultisol di Desa Petunang Kabupaten musi rawas menunjukan hasil yang terbaik baik pada sisi pertumbuhan dan produksi jika dibandingkan dengan varietas lainnya
\end{abstract}

Kata kunci : Sorgum, Varietas, Ultisol

\section{PENDAHULUAN}

Tanaman sorgum dapat menjadi tanaman alternatif yang tepat untuk di tanam pada lahan kering, diamana tanaman sorgum mampu tumbuh dan berproduksi pada lahan kering serta pada lahan kurang subur (Sumarsono dan Karsono, 1995) dan (Bahri,2015). Tanaman Sorgum berasal dari Afrika (Dahlberg et al.,2011). Sorgum merupakan salah satu tanaman serealia yang sangat potensial untuk digunakan sebagai sumber bahan pangan dan pakan alternatif. Sorgum memiliki beberapa keunggulan seperti dapat tumbuh di lahan kering, resiko kegagalan relatif kecil, kandungan nutrisi cukup tinggi, relatif lebih tahan hama penyakit serta pembiayaan usahatani relatif murah. Tanaman sorgum memiliki manfaat yang cukup banyak, antara lain seperti batang, daun, dan biji dapat dimanfaatkan baik untuk memenuhi kebutuhan pangan dan pakan ternak (Tacoh et al 2016). Selain sebagai bahan pangan, sorgum juga dimanfaatkan sebagai pakan, energi dan industri, produksi sorgum di Indonesia masih sangat rendah, bahkan secara umum produk sorgum belum tersedia di pasarpasar. Total luas tanaman sorgum untuk keperluan pangan, pakan dan energi dari tahun ke tahun terus meningkat di USA telah mencapai 5,7 juta hektar, India 15,8 juta hektar, Australia 2,5 juta hektar, China 8,7 juta hektar dan di Indonesia baru mencapai 8000 hektar yang tersebar di berbagai daerah (Supriyanto, 2010).

Masih rendahnya produksi sorgum di Indonesia sehingga perlu dilakukan upaya guna meningkatkan produksi tanaman sorgum, salah langkah guna meningkatkan produksi sorgum diantaranya dengan pemanfaatan lahan marginal. Mulyani dan Sarwani (2013) menyatakan bahwa Indonesia memiliki lahan marjinal seperti lahan kering masam seluas 108.8 juta ha Lahan kering masam cenderung memiliki ketersediaan $\mathrm{P}$ yang rendah. Lahan kering di Indonesia lebih dari separuh daratan (78\% luas daratan), salah satunya adalah lahan dengan Ordo Ultisol. Bahri 2016; Bahri 2020 menyatakan kendala usaha pertanian dilahan kering diantaranya kesuburan tanah yang rendah, kadar air tanah (kelengasan tanah) serta pH tanah yang rendah. (Subagyo et al., 2004), Tanah Ultisol di Indonesia memiliki sebaran 
yang luas yakni 45.794.000 ha atau sekitar $(25 \%)$ dari total luas dataran dengan sebaran di kalimantan 21.938.000 ha, Sumatera 9.469.000 ha, Maluku dan Papua

8.959.000 ha, Sulawesi 4.303.000 ha, Jawa 1.172.000 ha, dan Nusa Tenggara 53.000 ha.

Selain pengembangan tanaman sorgum di lahan marginal (suboptimal) juga dilakukan upaya untuk memilih vareitas yang cocok pada kondisi iklim mikro pada suatu kawasan. Kabupaten Musi Rawas Kabupaten Musi Rawas memiliki iklim tropis basah dengan kelembaban udara 87,0 persen dan rata-rata penyinaran matahari sebesar 61,9 persen. Temperatur maksimum $32,9^{\circ} \mathrm{C}$ dan temperatur minimum $19,6^{\circ} \mathrm{C}$. Sebagai daerah tropis basah, rata-rata curah hujan di Kabupaten Musi Rawas cukup tinggi, yaitu 2.285 per tahun dan rata-rata hari hujan 116 hari

hujan per tahun dengan bulan kering hanya empat bulan (Juni, Juli, Agustus dan September), maka wilayah ini termasuk dalam tipe curah hujan B (sangat basah). Kabupaten

Musi Rawas memiliki luas sebesar

$6.357,17 \mathrm{~km}^{2}$. penggunaan wilayah di Kabupaten Musi Rawas terbagi atas dua jenis yaitu tanah sawah dan tanah kering. Penggunaan wilayah tanah sawah meliputi sawah irigasi teknis, setengah teknis, irigasi sederhana, irigasi desa, tadah hujan, lebak dan kolam/tambak. Total luas tanah sawah adalah $192,622 \mathrm{~km}^{2}$ (3,03 persen) dan penggunaan tanah kering seluas 6.150,562 $\mathrm{km}^{2}$ (96,75persen). Podsolik merah kuning (ultisol) merupakan jenis tanah yang terluas di kabupaten musi rawas yakni sebesar 38 persen dari luas lahan yang ada sedangkan sisanya diantaranya 29 persen asosiasi podsolik, 16 persen kompleks podsolik, 8 persen aluvial, 7 persen litosol, 1 persen asosiasi litosol, dan 1 persen ligosol. Berdasarkan data BPS. 2020 Kecamatan Tuah Negeri memiliki luas wilayah 241,91 $\mathrm{km}^{2}$ yang terdiri dari 11 desa. Desa Petungan merupakan salah satu desa yang secara adminsitratif masuk dalam Kecamatan Tuah Negeri dengan luas desa $7,93 \mathrm{~km}^{2}$ yang didominasi dengan lahan kering, komoditas utama di desa petunang adalah tanaman perkebunan diantaranya tanaman sawit dan karet. Potensi pengembangan dikabupaten musi rawas sebenarnya sorgum cukup potensial. Berdasarkan hasil penelitian Bahri (2016) potensi hasil tanaman sorgum bisa mencapai 10,16 ton.ha ${ }^{-1}$. Novianto, et.al., (2020) pengembangan tanaman sorgum masih terkendala beberapa faktor diantaranya aspek budidaya, belum terciptanya pasar dan jaminan harga, pengelolaan dan industri, dan aspek kelembagaan. Surya (2007) belum berkembangnya budidaya tanaman sorgum di Indonesia salah satunya disebabkan sedikitnya varietas yang ada di Indonesia dan masih rendahnya perkembangan tanaman sorgum dapat disebabkan oleh rendahnya keragaman genetik dan produktivitas dari tanaman tersebut. Berdasarkan hal tersebut maka dilakukan penelitian keragaan lima varietas tanaman sorgum di desa petunang untuk mencari varietas tanaman sorgum yang adaktif terhadap kondisi tanah dan iklim sehingga bisa didapatkan gambaran untuk pengembangan tanaman sorgum sebagai tanaman pangan dan pakan alternatif di Kabupaten Musi Rawas.

\section{METODELOGI PENELITIAN}

Penelitian ini dilakukan dengan menggunakan metode Rancangan Acak Kelompok (RAK) non faktorial yang disusun dengan 5 perlakuan dan di ulang sebanyak 4 Faktor yang di uji yaitu: V1 = Varietas Pahat, V2 = Varietas Kawali, V3 = Varietas Numbuh, V4 $=$ Varietas Suri 4, dan V5 = Varietas Super 1 .

\section{HASIL DAN PEMBAHASAN Hasil}

Berdasarkan hasil analisis keragaman menunjukan bahwa keragaan lima varietas sorgum berpengaruh sangat nyata terhadap semua peubah yang diamati. 
Tabel 1. Hasil Analisis Keragaman Lima Varietas Sorgum

\begin{tabular}{|c|l|c|c|}
\hline No. & Peubah yang diamati & Varietas & KK \% \\
\hline 1 & Tinggi Tanaman $(\mathrm{cm})$ & $39,97 * *$ & 7,36 \\
\hline 2 & Diameter Batang $(\mathrm{cm})$ & $8,40 * *$ & 9,08 \\
\hline 3 & Umur Berbungga (hst) & $3,35 *$ & 8,45 \\
\hline 4 & Jumlah Daun (helai) & $14,84 * *$ & 7,26 \\
\hline 5 & Berat Basah Berangkasan $(\mathrm{g})$ & $33,34 * *$ & 9,79 \\
\hline 6 & Berat Biji Pertanaman $(\mathrm{g})$ & $32,28 * *$ & 10,83 \\
\hline 7 & Produksi per petak $(\mathrm{g})$ & $66,13 * *$ & 8,16 \\
\hline
\end{tabular}

Keterangan : ${ }^{*} *$ Pengaruh Sangat Nyata, $\mathrm{KK}=$ Koefisien Kerangan

Tabel. 2. Hasil Uji BNJ dan Data Tabulasi Lima Varietas Sorgum Bicolor

\begin{tabular}{|c|c|c|c|c|c|c|c|c|}
\hline \multirow[t]{2}{*}{ No } & \multirow{2}{*}{$\begin{array}{c}\text { Peubah yang di } \\
\text { amati }\end{array}$} & \multicolumn{5}{|c|}{ Perlakuan tanah ultisol } & \multicolumn{2}{|c|}{ BNJ } \\
\hline & & V1 & $\mathbf{V 2}$ & V3 & V4 & V5 & $5 \%$ & $1 \%$ \\
\hline 1 & $\begin{array}{l}\text { Tinggi } \\
\text { Tanaman }(\mathrm{cm})\end{array}$ & $\begin{array}{c}132,25 \mathrm{a} \\
\mathrm{A}\end{array}$ & $\begin{array}{c}179,50 \\
b B\end{array}$ & $\begin{array}{l}257,00 \\
\mathrm{cC}\end{array}$ & $\begin{array}{c}211,50 \\
\mathrm{bcBC}\end{array}$ & $\begin{array}{l}198,25 \\
\mathrm{bcBC}\end{array}$ & 32,50 & 37,64 \\
\hline 2 & $\begin{array}{l}\text { Diameter Batang } \\
(\mathrm{cm})\end{array}$ & $1,45 \mathrm{aA}$ & $\begin{array}{c}1,70 \mathrm{abA} \\
\mathrm{B}\end{array}$ & $\begin{array}{c}2,0 \\
\mathrm{bcBC}\end{array}$ & $\begin{array}{c}2,03 \\
\mathrm{bcBC}\end{array}$ & $\begin{array}{c}1,85 \\
\mathrm{bcBC}\end{array}$ & 0,37 & 0,43 \\
\hline 3 & $\begin{array}{l}\text { Umur Berbungga } \\
\text { (Hst) }\end{array}$ & $58,50 \mathrm{cC}$ & $66,25 \mathrm{eE}$ & $60,50 \mathrm{dD}$ & $50.50 \mathrm{bB}$ & $54,25 \mathrm{aA}$ & 11,28 & 13,06 \\
\hline 4 & $\begin{array}{l}\text { Jumlah daun } \\
\text { (Helai) }\end{array}$ & $6,25 \mathrm{aA}$ & $\begin{array}{c}7,50 \\
\mathrm{abAB}\end{array}$ & $\begin{array}{l}9,25 \\
\mathrm{cBC}\end{array}$ & $\begin{array}{l}7,75 \\
b c B c\end{array}$ & $\begin{array}{c}7,50 \\
\mathrm{abAB}\end{array}$ & 1,25 & 1,45 \\
\hline 5 & $\begin{array}{l}\text { Berat Basah } \\
\text { Berangkasan (g) }\end{array}$ & $\begin{array}{c}271,50 \mathrm{a} \\
\mathrm{A}\end{array}$ & $\begin{array}{c}583,50 \\
b c B C\end{array}$ & $\begin{array}{c}645,75 \\
\mathrm{cC}\end{array}$ & $\begin{array}{r}621,75 \\
\mathrm{bcBC}\end{array}$ & $\begin{array}{c}559,00 \\
\text { bB }\end{array}$ & 118,40 & 137,13 \\
\hline 6 & $\begin{array}{l}\text { Berat Biji } \\
\text { Pertanaman }(g)\end{array}$ & $\begin{array}{c}40,75 a \\
\text { A }\end{array}$ & $\begin{array}{l}77,50 \\
b c B C\end{array}$ & $\begin{array}{c}102,25 \\
\mathrm{Cc}\end{array}$ & $\begin{array}{l}97,00 \\
\mathrm{cdCD}\end{array}$ & $75,00 \mathrm{bB}$ & 19,20 & 22,24 \\
\hline 7 & $\begin{array}{l}\text { Produksi Per } \\
\text { Petak }(\mathrm{g})\end{array}$ & $\begin{array}{c}566,50 \mathrm{a} \\
\mathrm{A}\end{array}$ & $\begin{array}{c}1116,25 \\
b B\end{array}$ & $\begin{array}{c}1711,50 \\
\mathrm{cC}\end{array}$ & $\begin{array}{c}1405,25 \\
\text { bcBC }\end{array}$ & $\begin{array}{c}1233,26 \\
\mathrm{bcBC}\end{array}$ & 234,15 & 271,19 \\
\hline
\end{tabular}

Keterangan: Angka-angka yang di ikuti huruf yang sama pada baris yang sama berarti berbeda tidak nyata pada taraf uji BNJ $5 \%$ dan $1 \%$

adaptasi lima varietas sorgum bicolor L di tanah ultisol berpengaruh sangat nyata terhadap tinggi tanaman. Sorgum varietas V3 (Numbuh) menghasilkan tanaman tertinggi yaitu $(257,00 \mathrm{~cm})$. Hasil Uji BNJ menunjukan bahwa perlakuan V3 berbeda sangat nyata dengan V1 dan V2 serta berbeda nyata terhadap perlakuan V4 dan V5

\section{Tinggi Tanaman $(\mathrm{cm})$}

Berdasarkan analisis

keragaman menunjukan bahwa perlakuan uji 


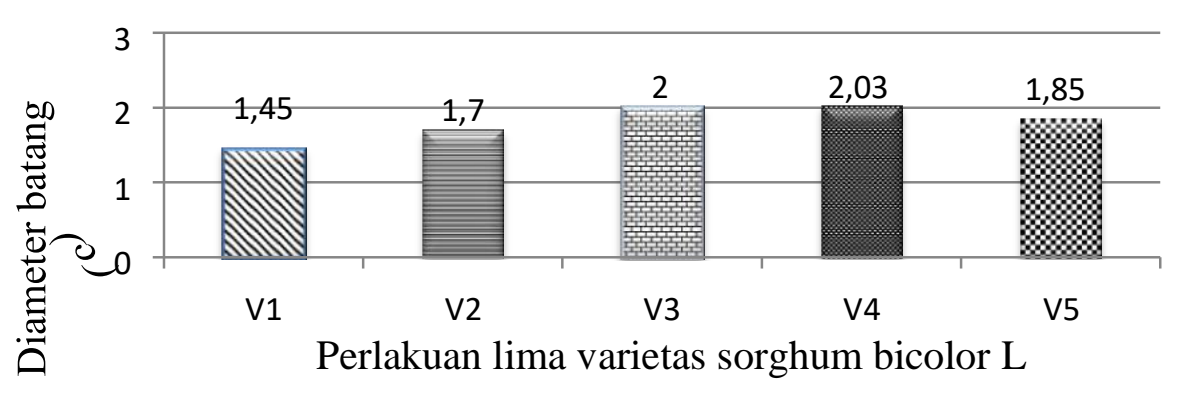

Gambar 2. Diagram uji adaptasi lima varietas sorgum bicolor 1 tehadap diameter batang $(\mathrm{cm})$

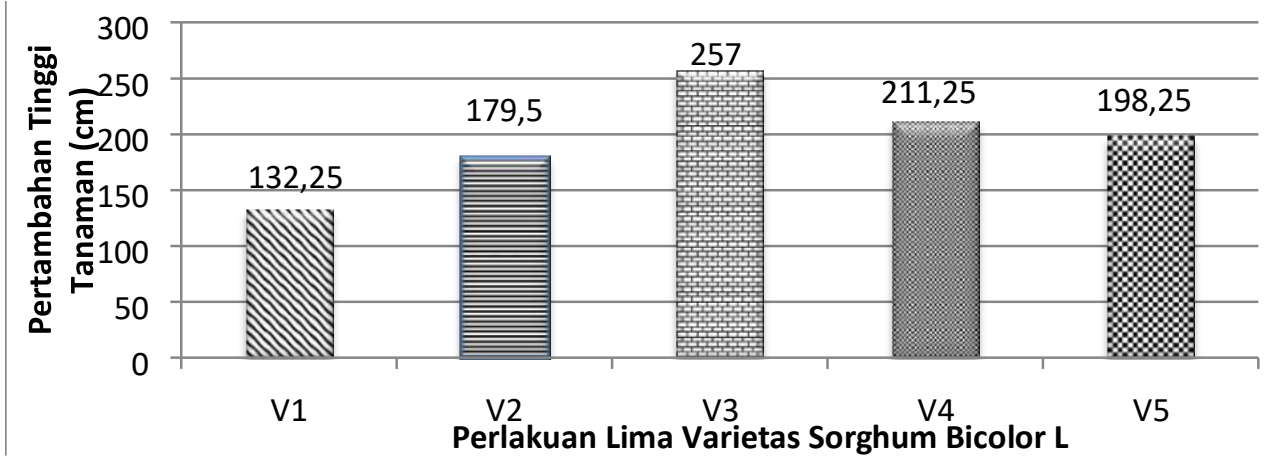

Diagram uji adaptasi lima varietas sorgum bicolor 1 tehadap tinggi tanaman $(\mathrm{cm})$

Gambar 1.

ultisol berpengaruh sangat nyata terhadap

\section{Diameter batang (cm)}

Berdasarkan analisis keragaman menunjukan bahwa perlakuan uji adaptasi lima varietas sorgum bicolor di tanah 3. Umur berbungga (hst)

Berdasarkan analisis keragaman menunjukan bahwa perlakuan uji adaptasi lima varietas sorgum bicolor di tanah ultisol berpengaruh sangat nyata terhadap umur berbunga. Hasil uji BNJ dan data tabulasi uji diameter batang (gambar 2). sorgum varietas V4 Suri 1 menghasilkan diameter batang terbesar yaitu $(2,03 \mathrm{~cm})$. Hasil Uji BNJ menunjukan bahwa perlakuan V4 berbeda sangat nyata dengan V1 dan V2 serta berbeda nyata terhadap perlakuan V3 dan V5

berbungga dapat di lihat pada gambar 3 . Bahwa sorgum varietas V5 (Super 1) menghasilkan umur berbunga paling cepat yaitu (54,25 hst). Hasil Uji BNJ menunjukan bahwa perlakuan V5 berbeda sangat nyata dengan V2 dan V3 serta berbeda nyata terhadap perlakuan $\mathrm{V} 1$ dan $\mathrm{V} 4$

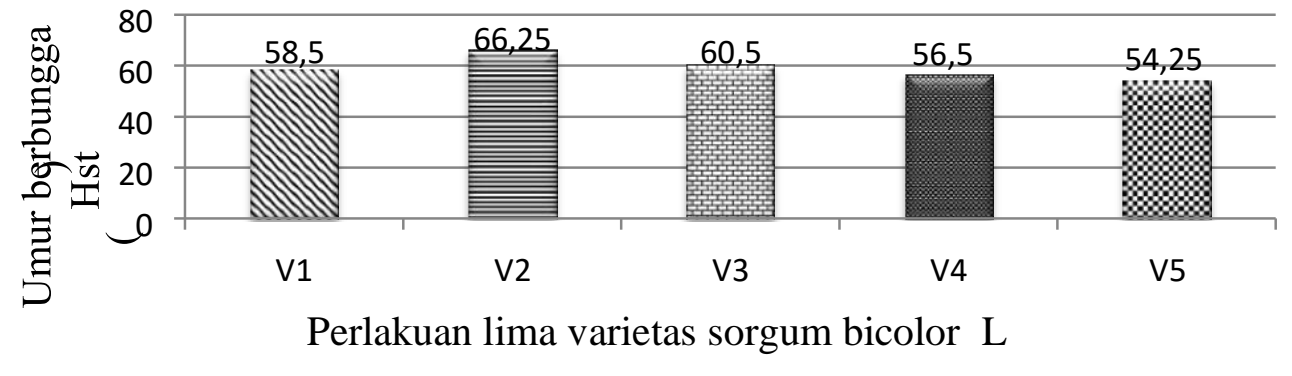

Gambar 3. Diagram uji adaptasi lima varietas sorgum bicolor 1 tehadap lama umur berbunga (hst) adaptasi lima varietas sorghum terhadap umur

\section{Jumlah Daun (helai)}

Berdasarkan analisis keragaman menunjukan bahwa perlakuan uji adaptasi lima varietas sorgum bicolor di tanah ultisol berpengaruh sangat nyata terhadap jumlah daun. Hasil uji BNJ dan data tabulasi uji adaptasi lima varietas sorghum

terhadap jumlah daun dapat di lihat pada gambar 4.

Sorgum varietas V3 (Numbuh) menghasilkan daun paling banyak yaitu $(9,25$ helai). Hasil Uji BNJ menunjukan bahwa perlakuan V3 berbeda sangat nyata dengan V1, V2 dan V5 serta berbeda nyata terhadap perlakuan $\mathrm{V} 4$ 


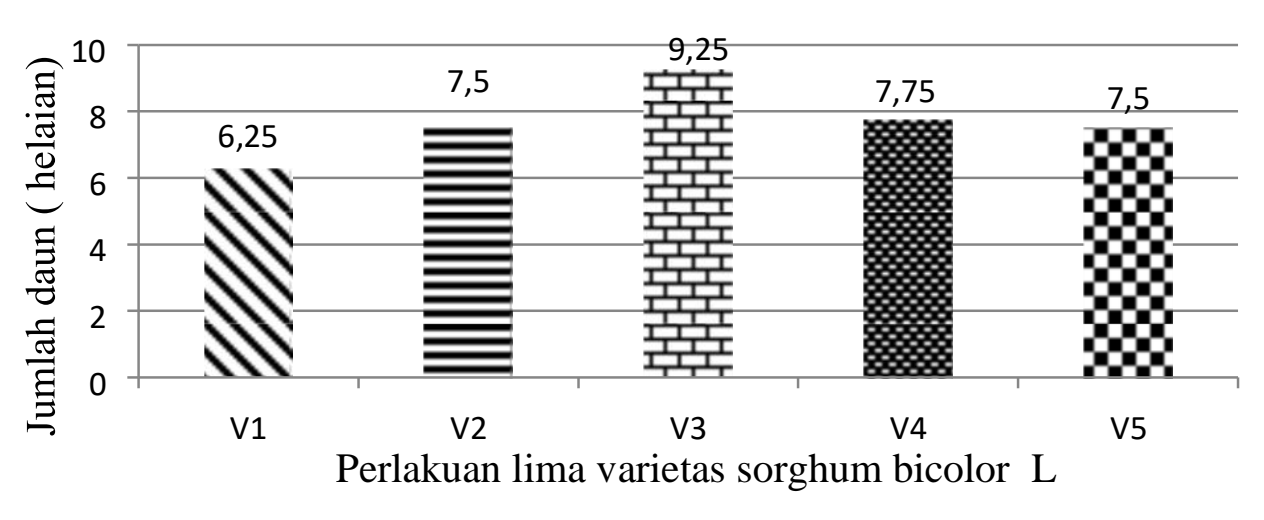

Gambar 4.

Diagram Uji Adaptasi Lima Varietas Sorgum Bicolor L Tehadap jumlah daun

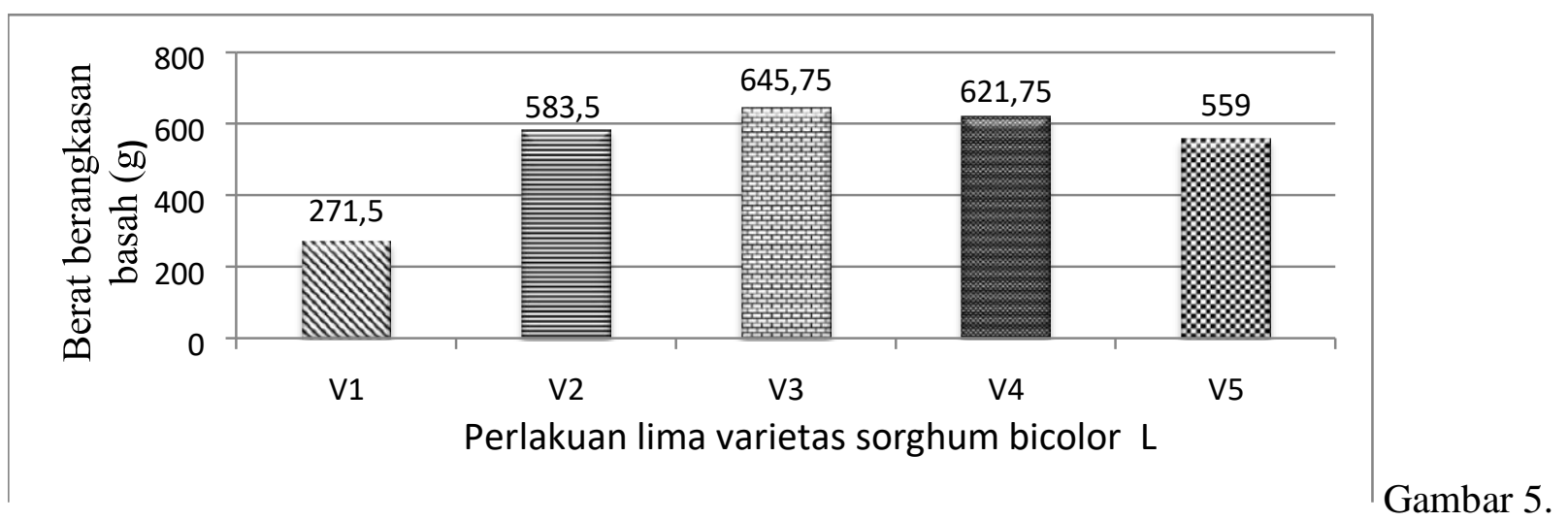

Diagram uji adaptasi lima varietas sorgum bicolor 1 tehadap berat berangkasan basah

\section{Berat BasahBerangkasan (g)}

Berdasarkan hasil analisis keragaman menunjukan bahwa perlakuan uji adaptasi lima varietas sorghum bicolor di tanah ultisol berpengaruh sangat nyata terhadap berat berangkasan basah. Hasil uji BNJ dan data tabulasi uji adaptasi lima varietas sorghum 6.Berat Biji Pertanaman (g)

Berdasarkan analisis keragaman menunjukan bahwa perlakuan uji adaptasi lima varietas sorghum bicolor di tanah ultisol berpengaruh sangat nyata terhadap berat biji pertanaman. Hasil uji BNJ dan data tabulasi uji adaptasi lima varietas sorghum terhadap berat biji pertanaman dapat di lihat pada gambar 6 sorgum varietas V3 (Numbuh) menghasilkan Berat biji pertanaman paling berat yaitu $(101,25 \mathrm{gr})$. terhadap berat berangkasan basah dapat di lihat pada gambar 5. Sorgum varietas V3(Numbuh) menghasilkan Berat berangkasan basah paling berat yaitu $(645,75$ g). Hasil Uji BNJ menunjukan bahwa perlakuan V3 berbeda sangat nyata dengan V1 dan V2 serta berbeda nyata terhadap perlakuan V4 dan V5

Hasil Uji BNJ menunjukan bahwa perlakuan V3 berbeda sangat nyata dengan V1 dan V2 serta berbeda nyata terhadap 
adaptasi lima varietas sorgum bicolor 1 tehadap produksi perpetak

Gambar 6.

Diagram uji

Gambar 3.7.

Diagram uji
Berdasarkan analisis kera gaman menunjukan bahwa perlakuan

uji adaptasi lima varietas sorghum bicolor di tanah ultisol berpengaruh sangat nyata terhadap berat biji pertanaman. Hasil uji

\section{PEMBAHASAN}

Hasil analisis menunjukan bahwa Uji Adaptasi Lima Varietas Sorgum Bicolor Di Tanah Ultisol berpengaruh sangat nyata terhadap Tinggi tanaman, Diameter Batang, Umur Berbunga, Jumlah Daun ,Berat Basah Berangkasan, Berat Biji Pertanaman dan Produksi Per Petak. Terjadinya pengaruh sangat nyata karena perbedaan antar varietas sorgum yang diteliti yang menyebabkan terjadinya perbedaan pertumbuhan dan produksi antar varietas tersebut. Berdasarkan hasil penelitian menunjukan bahwa varietas Pahat,Kawali,Numbuh,Suri 4 dan Super 1 mempunyai tinggi tanaman masing-masing adalah $132,25 \mathrm{~cm}, 179,50 \mathrm{~cm}, 257,00 \mathrm{~cm}$, $211,50 \mathrm{~cm}$ dan 198,25 cm . Sedangkan berdasarkan deskripsi tinggi tanaman masingmasing adalah $187 \mathrm{~cm}, 235 \mathrm{~cm}, 287$ $\mathrm{cm}, 239 \mathrm{~cm}$ dan $204 \mathrm{~cm}$, hal ini menunjukan bahwa tinggi tanaman yang di teliti lebih rendah dari pada deskripsi.

$\begin{array}{ll}\begin{array}{l}\text { Pada peubah } \\ \text { batang menunjukan }\end{array} & \text { diameter } \\ \text { varietas } & \end{array}$

Pahat,Kawali,Numbuh,Suri 4 dan Super 1 mempunyai ukuran diameter batang masingmasing $1,45 \mathrm{~cm}, 1,70 \mathrm{~cm}, 2,00$ $\mathrm{cm}, 2,03 \mathrm{~cm}$ dan $1,85 \mathrm{~cm}$ ini bearti diameter batang yang paling besar terdapat pada varietas suri 4 .
V3/ Numbuh menghasilkan produksi paling berat yaitu $(1711,50$ gr) Hasil Uji BNJ menunjukan bahwa perlakuan V3 berbeda sangat nyata dengan V1 dan V2 serta berbeda nyata terhadap

Kemudian pada peubah varietas Pahat,Kawali,Numbuh,Suri 4 dan Super 1 mempunyai umur berbunga masingmasing adalah 58,50 hari, 66,25 hari, 60,50 hari, 56,50 hari dan 54,25 hari. Sedangkan berdasarkan deskripsi masing-masing umur berbunga 60 hari,70 hari,69 hari, 56 hari dan 55 hari. Hal ini menunjukan bahwa umur berbunga yang di teliti lebih cepat dari pada deskripsi. Selanjutnya pada peubah varietas Pahat, Kawali, Numbuh, Suri 4 dan Super 1

mempunyai jumlah helaian daun masingmasing adalah 6,25 helai, 7,50 helai , 9,25 helai,, 7,25 helai dan 7,50 helai. Sedangkan berdasarkan deskripsi masingmasing jumlah helaian daun 8 helaian, 10 helaian, 12 helaian, 10 helaian dan 10 helaian. Hal ini menunjukan bahwa jumlah helaian daun yang di teliti lebih sedikit dari pada deskripsi.

Pada peubah varietas Pahat, Kawali, Numbuh, Suri 4 dan Super 1 mempunyai berat berangkasan basah masing-masing adalah 271,50g , $583,50 \mathrm{~g}, 645,75 \mathrm{~g}, 621,75 \mathrm{~g}$ dan 559,00g artinya yang mempunyai berat berangkasan basah paling berat terdapat pada varietas Numbuh.

Kemudian pada peubah berat biji pertanaman varietas Pahat, Kawali, Numbuh, Suri 4 dan Super 1 mempunyai berat biji pertanaman masing-masing adalah 40,75 g, 77,50 g, 102,25 g, $97,00 \mathrm{~g}$ dan 75,50 g artinya yang mempunyai berat biji pertanaman paling berat terdapat pada varietas Numbuh. Pada peubah varietas Pahat,Kawali,Numbuh,Suri 4 dan Super 1 
mempunyai produksi perpetak masing-masing adalah $(566,50 \mathrm{~g} /$ perpetak setara dengan $1.888 \mathrm{t} / \mathrm{h})$, $(1116,50 \mathrm{~g}$ setara dengan $3.720 \mathrm{t} / \mathrm{h}),(1711,50 \mathrm{~g}$ setara dengan

$5.705 \mathrm{t} / \mathrm{h})$, (1405,25 g setara dengan $4.684 \mathrm{t} / \mathrm{h})$ dan $(1233,25 \mathrm{~g}$ setara dengan $4.111 \mathrm{t} / \mathrm{h}$ ) sedangkan berdasarkan deskripsi produksi masing-masing; $3 \mathrm{t} / \mathrm{h}$, $5 \mathrm{t} / \mathrm{h}, 6,3 \mathrm{t} / \mathrm{h}, 5,7 \mathrm{t} / \mathrm{h}$ dan $5,5 \mathrm{t} / \mathrm{h}$. Hal ini menunjukan bawah produksi perpetak yang diteliti lebih rendah daripada deskripsi. Dan dari semua peubah yang diamati menunjukan bahwa semuanya berpengaruh sangat nyata.

Hasil tabulasi dan uji BNJ menunjukan Dari lima varietas sorgum yang di uji adaptasikan varietas numbuh yang paling baik pertumbuhan dan produksinya. Sorgum numbuh sangat cocok dibudidayakan di lahan kering karena kebutuhan terhadap air lebih sedikit dibandingkan dengan varietasvarietas lainya. Menurut Tacoh et al.,(2017). Sorgum varietas Numbuh memiliki beberapa keunggulan seperti dapat tumbuh di lahan kering, resiko kegagalan relatif kecil, kandungan nutrisi cukup tinggi, relatif lebih tahan hama penyakit dibandingkan tanaman pangan lainnya serta pembiayaan usahatani relative murah serta mudah beradaptasi dengan lingkungan nya. Hal ini dikarenakan kemampuan tanaman sorghum jenis numbuh mampu beradaptasi lebih baik dengan lingkungan menjadi salah satu faktor pertumbuhan tanaman ini lebih menonjol dari pada jenis yang lainya. Selain itu menurut Effendi (2012) pertumbuhan yang berbeda antar varietas sorgum diduga disebabkan oleh adanya perbedaan kecepatan pembelahan, perbanyakan dan pembesaran sel.

Zulkarnaenet al (2015) menyatakan bahwa varietas merupakan sekumpulan individu tanaman yang dapat dibedakan oleh setiap sifat (morfologi, fisiologi, sitology dan kimia)

Namun demikian jika dibandingkan dengan deskripsi pada lampiran.2 semua peubah yang di amati lebih rendah di bandingkan dengan deskripsi. Hal ini terjadi karena beberapa faktor yang pertama yaitu kondisi tanah ultisol yang mempunyai $\mathrm{pH}$ rendah dan miskin akan unsur hara yang menyebabkan terhambatnya pertumbuhan dan produksi pada setiap varietas sorgum tersebut.pada analisa tanah kandungan $\mathrm{Ph}$ 4,36, N\% 0,06, P tersedia 8,85, K-dd 0,19 dan AL-dd 2,88 Dapat di lihat pada dilampiran 18 tabel 4.3 dimana $\mathrm{pH}$ dan kandungan unsur hara pada tanah ultisol sangat rendah hal ini sesuai dengan Menurut pendapat Prasetyoet al (2005) Reaksi tanah Ultisol pada umumnya masam hingga sangat masam pH 5-3. Dan tanah ultisol dicirikan oleh adanya akumulasi liat pada horizon bawah permukaan sehingga mengurangi daya resap air dan meningkatkan aliran permukaan dan erosi . Hal ini karena kesuburan tanah ultisol hanya ditentukan oleh kandungan bahan organik pada lapisan atas. Bila lapisan ini tererosi maka tanah menjadi miskin bahan organik dan hara. Tanah ini juga miskin kandungan hara terutama $\mathrm{P}$ dan kationkation dapat ditukar seperti $\mathrm{Ca}, \mathrm{Mg}, \mathrm{Na}$, dan $\mathrm{K}$, kadar Al tinggi, kapasitas tukar kation rendah, dan peka terhadap erosi (Sri Adiningsih dan Mulyadi 1993).

Kemudian adalah faktor iklim Perubahan iklim merupakan sesuatu yang sulit untuk dihindari dan memberikan dampak terhadap berbagai segi kehidupan. Pertanian diketahui merupakan sektor yang paling rentan terhadap dampak perubahan iklim.Dampak perubahan iklim ekstrim berupa kekeringan menempati urutan pertama penyebab gagal panen. Kondisi ini berimplikasi terhadap penurunan produksi dan kesejahteraan petani (Hadi et al. 2000). Terdapat hubungan erat antara perubahan iklim dan produksi pertanian (Winarto et al. 2013). Pengaruh perubahan iklim terhadap pertanian bersifat multidimensional, mulai dari sumber daya, infrastruktur pertanian, dan sistem produksi, hingga ketahanan pangan, kesejahteraan petani dan masyarakat pada umumnya..sehingga menyebabkan menurunya kualitas dan produksi pada tanaman sorgum yang menyebabkan kerugian secara finansial. Selanjutnya faktor penentu ketersediaan air bagi tanaman sorgum adalah curah hujan. Ketersediaan air merupakan faktor utama yang membatasi tingkat produksi tanaman sorghum . Ketersediaan air bagi tanaman sorgum di lapangan diperoleh dari curah hujan. Tinggi rendahnya curah hujan dapat dilakukan sebagai evaluasi produksi untuk tahuntahun ke depan. Menurut Sunarko (2007) penyebaran produksi setiap bulan dalam setahun sangat dipengaruhi oleh curah hujan pada tahun- 
tahun sebelumnya. Hal ini berimplikasi terhadap tanaman sorgm yang di teliti

\section{KESIMPULAN DAN SARAN}

Berdasarkan hasil penelitian terhadap keragaan lima varietas yang diujikan dapat disimpulkan Varietas Numbuh menghasilkan pertumbuhan dan produksi yang terbaik dibandingkan dengan empat varietas lainnya. Untuk penaman sorgum aspek pengelolaan hara pada kegiatan budidaya mutlak dilakukan sehingga hasil bisa sesui dengan harapan.

\section{DAFTAR PUSTAKA}

Abdul Muis,Sulistyawatidan A. ZainulArifin. 2018.’Pengaruh pemberian kombinasi pupuk npk dan pupuk kandang sapi terhadap pertumbuhan dan hasil tanaman sorgum (Sorghum bicolor L.) Jurnal Agroteknologi Volume 2 Nomor 1

Bahri.S., Dedik Budianta, Munandar. 2015. Perubahan C Organik, pH dan KTK

Tanah Akibat Aplikasi Biochar dan Pupuk Kandang Ayam pada Tanah Ultisol serta Pengaruhnya terhadap Pertumbuhan dan Produksi

Tanaman

Sorgum, Proseding Seminar Nasional

Hal. 293-300 Semirata BKS-PTN

Barat. Palangkaraya, 20-21

Agustus

2015

Bahri.S., Dedik Budianta, Munandar. 2016. Perubahan Beberapa Sifat Kimia

Tanah dengan Pemberian Biochar dan

Pupuk Kandang Ayam pada Tanah Ultisol. Jurnal Klorofil Volume XI Nomor 2, Hal 77-84

Bahri, S, Merismon, dan Sutejo. 2020.

Pemanfaatan Biochar dan Pupuk Kandang Ayam pada Pertanaman Jagung Hibrida di Tanah Ultisol. Jurnal

Galung Tropika Volume 9 Nomor 2 ,
Hal 115-123

Badan Pusat Statistik (BPS). 2020.

Kecamatan Tuah Negeri dalam

Angka. Badan Pusat Statistik

Kabupaten Musi Rawas.

Momongan Daniel Jorex,

Trikoesoemaningtyas, Wirnas

Desta dan Sopandie Didy. 2018.

Potensi

Hasil dan Toleransi Galur-galur Inbrida

Sorgum pada Tanahdengan Hara

Fosfor). di unduh dari https://dx.doi.org/10.24831/jai.v47i

1.2

2629/April 2019, 47(1):39-46

Novianto, Bahri, S, Ibrahim.W. 2020.

Respon Kelompok Tani dalam Pemanfaatan Lahan Suboptimal Melalui Pengembangan Budidaya Tanaman Sorgum. Laporan Pengabdian Masyarakat. LPPM UNMURA Tacoh Edward, A.Rumambi dan W.B. Kaunang. 2017. Pengaruh pemanfaatan pupuk bokasi feses sapi terhadap produksi sorgum varietas kawali. Jurnal zootek volume. 37 no, 1: 88-95 Fakultas Peternakan Universitas Sam Ratulangi Manado,95115

Ratna Suminar, Suwarto dan Heni Purnamawati.2017.Pertumbuhan dan Hasil Sorgum di Tanah Latosol denganAplikasi Dosis Pupuk Nitrogen dan Fosfor yang Berbeda.Diunduh darittps://dx.doi.org/10.24831/jai.v45i3.

14515.Institut Pertanian Bogor(Bogor Agricultural University), J1. Meranti, Kampus IPB Darmaga, Bogor 16680, Indonesia

Gusnidar, Annisa Fitri, dan Syafrimen Yasin.2019.Titonia Dan Jerami Padi Yang Dikomposkan TerhadapCiri Kimia Tanah Dan Produksi Jagung Pada

Ultisol.J. Solum Vol. XVI No. 1, Januari 2019: 11-18.Prodi Ilmu Tanah Fakultas Pertanian Universitas Andalas Padang Sumatera Barat 25163

Edward Tacoh, A. Rumambi

*,W.B.Kaunang.2017. Pengaruh Pemanfaatan Pupuk Bokasi Feses Sapi Terhadap Produksi

Sorgum Varietas Kawali. Jurnal Zootek ("Zootek"

Journal ) Vol. 37 No. $1: 88-95$

Dewi HiasintaTarigan, T. Irmansyah, Edison 
Purba.2013. Pengaruh Waktu Penyiangan Terhadap Pertumbuhan Dan ProduksiBeberapa Varietas Sorgum (Sorgum Bicolor (L.) Moench) Jurnal Online AgroekoteknologiIssn No. 2337- 6597Vol.2, No.1: 86-94

Leonard Septian Munthe, 2012. Respons

Pertumbuhan dan Produksi TigaVarietas Sorgum (Sorghum bicolor(L.) Moench) Dengan

Perbedaan Sistem Pengolahan Tanah. SkripsiFakultas Pertanian Universitas Sebelas Maret.

Prasetyo, B. Subardja, dan B. Kaslan. 2005.Ultisols dari bahan volkan andesitic di lerengbawah G. Ungaran.

Jurnal Tanah dan Iklim23: 1-12.

Rahayu, M., Samanhudi dan Wartoyo. 2012. Uji adaptasi beberapa varietas sorgum manis di lahan kering wilayah Jawa Tengah dan Jawa Timur. Jurnal

IlmuPertanian, 27 (1), 1-10.

Yulnafatmawita. 2006. Hubungan antarastatus Corganik dan stabilitasaggregat tanah Ultisol
Limau Manispada Beberapa penggunaan lahan.Solum J. Vol III No.1 Jan 2006.

Prasetyo, B. dan Suriadikarta, D.A. 2012.Karakteristik, potensi, dan teknologi pengelolaan Ultisol untuk pengembangan pertanian lahan kering diindonesia. Jurnal Litbang Pertanian 25 (2), 39-44.

Ishak, M., Sudirja, R and Ismail, A. 2012. Zonasi kesesuaian lahan untuk pengembangan tanaman sorgum (Sorghum bicolor (L) Moench) di Kabupaten Sumedang berdasar analisis geologi, penggunaan lahan, iklim dan topografi. BionaturaJurnal Ilmuilmu Hayati dan Fisik .Vol. 14, No. 3, November : 173 183.

Sudaryono. 2009. Tingkat kesuburan tanah ultisol pada lahan pertambangan batubara sangatta, kalimantan timur dalam peneliti pusat teknologi lingkunganbadan pengkajian dan penerapan teknologi j. tek. ling vol.10 no.3 hal. 337 - 346 jakarta, sept 2009

issn 1441-318 